\title{
Pengaruh Cita Merek terhadap loyalitas Pasien di Poliklinik Orthopaedi RUMAH SAKIT KHUSUS BEDAH HALMAHERA Siaga - BANDUNG
}

\section{Bernadetta Echalaksmidewi Yudhasari Sukowati}

\author{
Program Studi Magister Manajemen Rumah Sakit Pascasarjana Universitas Islam Bandung \\ e-mail: bernadettaeys2@gmail.com
}

\begin{abstract}
This study aims to determine the effect of brand image on the loyalty of patients who come for treatment to the Polyclinic Orthopaedics RSKB Halmahera Siaga, Bandung. This type of research used is quantitative research with the research method using descriptive analysis and path analysis. The population used in this study were patients who went to the policlinic Orthopaedic Halmahera Siaga Hospital Special Surgery, Bandung with a sample of 224 orang. Teknik Proportional sampling is stratified random sampling process whereas the members of the sample population was randomly with regard strata in the population three orthopedic policlinic at the Halmahera Siaga Hospital Special Surgery, Bandung. Descriptive statistical calculations research results show that the variable types used brand associations is categories good., the favorability of brand association is categorized quite good, the strength of the association of brands is categories good, the uniqueness of brand associations association is categories good and loyalty of patients included in category quite good. Verification The results partially used type of brand association and uniqueness of brand associations significant effect on patient loyalty, but for the favorability of brand association and brand association strength was not significantly affect patient loyalty, simultaneously while the brand image significantly influence loyalty patients.
\end{abstract}

Keywords: Brand image, Patient Loyalty, Polyclinics

\begin{abstract}
Abstrak. Penelitian ini bertujuan untuk mengetahui pengaruh citra merek terhadap loyalitas pasien yang datang berobat ke Poliklinik Orthopaedi RSKB Halmahera Siaga, Bandung. Jenis penelitian digunakan adalah penelitian kuantitatif dengan metode penelitian menggunakan analisis deskriptif dan analisis jalur. Populasi yang di gunakan dalam penelitian ini adalah pasien yang berobat ke poliklinik Orthopaedi RS Khusus Bedah Halmahera Siaga, Bandung dengan jumlah sampel 224 orang. Teknik sampling yang digunakan adalah Proportional Stratified Random Sampling dimana pengambilan anggota sampel dari populasi dilakukan secara acak dengan memperhatikan strata dalam populasi tiga poliklinik orthopaedi di RS Khusus Bedah Halmahera Siaga, Bandung. Hasil penelitian perhitungan statistik deskriptif menunjukkan bahwa variabel jenis asosiasi merek yang digunakan termasuk dalam kategori baik., keunggulan asosiasi merek termasuk dalam kategori cukup baik, kekuatan dari asosiasi merek termasuk dalam kategori baik, keunikan dari asosiasi merek termasuk dalam kategori baik dan loyalitas pasien termasuk dalam kategori cukup baik. Hasil verifikatif secara parsial jenis asosiasi merekyang digunakan dan keunikan dari asosiasi merek berpengaruh signifikan terhadap loyalitas pasien, namun untuk keunggulan asosiasi merek dan kekuatan asosiasi merek tidak berpengaruh secara signifikan terhadap loyalitas pasien sedangakan secara simultan citra merek berpengaruh signifikan terhadap loyalitas pasien.
\end{abstract}

Kata kunci: Citra Merek, Loyalitas Pasien, Poliklinik 


\section{Pendahuluan}

Pada era globalisasi saat ini dimana perkembangan semua sektor sudah semakin terbuka luas, kualitas menjadi salah satu faktor yang sangat mendukung keberlangsungan semua jenis usaha termaksud juga didalamnya usaha pelayanan kesehatan. Rumah Sakit merupakan wadah dalam usaha pelayanan kesehatan, dituntut harus semakin meningkatkan kualitasnya, sehingga bisa bersaing dengan rumah sakit lain yang semakin hari semakin bertambah. Meskipun tuntutan usaha perumahsakitan harus memiliki aspek sosial tetapi aspek bisnis di dalam era globalisasi ini juga merupakan hal yang sangat wajar. Oleh karena itu promosi dan pemasaran rumah sakit tidak boleh dikesampingkan. Perusahaan atau organisasi yang didalam hal ini merupakan industri rumah sakit mampu memberikan pelayanan yang memiliki daya saing tinggi dan mampu mendominasi pasar (Widajat, 2009).

Pada saat ini persaingan bisnis rumah sakit di Kota Bandung sangat ketat, sampai tahun 2014, Bandung memiliki Rumah Sakit sebanyak 31 buah, Puskesmas 73 buah ditambah klinik pratama 80 buah dan klinik utama 46 buah.

Tabel 1. Jumlah Sarana Pelayanan Kesehatan di Kota Bandung

\begin{tabular}{|c|c|c|c|}
\hline & $\begin{array}{l}\text { Rumah } \\
\text { Sakit }\end{array}$ & Kepemilika n & Jumlah \\
\hline 1 & $\begin{array}{l}\text { RS. } \\
\text { Pemerinta }\end{array}$ & Depkes & 3 \\
\hline 2 & $\begin{array}{l}\text { RS. } \\
\text { Daera }\end{array}$ & Pemda & 3 \\
\hline 3 & RS.Swasta & Swasta & 21 \\
\hline
\end{tabular}

\begin{tabular}{|c|c|c|c|}
\hline 4 & $\begin{array}{l}\text { RS } \\
\text { TNI/POLR } \\
\text { I }\end{array}$ & TNI/POLRI & 3 \\
\hline 5 & RS. Gigi & Unpad & 1 \\
\hline 6 & Puskesmas & Pemda & 73 \\
\hline 7 & $\begin{array}{l}\text { Klinik } \\
\text { Pratama }\end{array}$ & Swasta & 80 \\
\hline 8 & $\begin{array}{l}\text { Klinik } \\
\text { Utama }\end{array}$ & Swasta & 46 \\
\hline
\end{tabular}

Berdasarkan data diatas terlihat dengan adanya jumlah rumah sakit yang cukup banyak dengan kualitas yang dituntut harus baik, ditambah lagi dengan kemungkinan penambahan rumah sakit di tahun-tahun mendatang. Hal ini merupakan suatu tantangan yang cukup berat bagi pengelola rumah sakit untuk bisa selalu meningkatkan pelayanannya agar bisa mempertahankan pasien dan menambah kunjungan pasien. Citra baik dan usaha pemasaran yang maksimal diharapkan bisa mempertahankan pasien, timbul kepuasan pasien yang pada akhirnya timbul kesetiaan pasien terhadap rumah sakit tersebut.

Rumah Sakit saat ini dituntut memiliki suatu unggulan yang bisa dijadikan suatu nilai yang akan memiliki kesan khusus terhadap pasien ataupun masyarakat. Oleh karena itu citra yang baik dalam pelayanan rumah sakit beserta strateginya menjadi keunggulan perusahaan dalam menghadapi persaingan dan tuntutan dari pasien rumah sakit. Hal tersebut diatas disampaikan berdasarkan teori penghubung antara citra merek dengan loyalitas konsumen dikutip dari Freddy Rangkuti (2002) yang menegaskan bahwa apabila konsumen beranggapan 
bahwa merek tertentu secara fisik berbeda dari merek pesaing, citra merek tersebut akan melekat secara terus menerus sehingga dapat membentuk kesetiaan terhadap merek tertentu.

Dari teori yang disampaikan oleh Freddy Rangkuti diatas terdapat kesenjangan yang terjadi di Poliklinik RSKB Halmahera Siaga.

Rumah Sakit Khusus Bedah Halmahera Siaga adalah sebuah fasilitas layanan kesehatan Khusus Bedah yang diselenggarakan oleh Yayasan Pengabdian Halmahera Husada, satu badan hukum non profit yang didirikan di depan notaris Komar Andasasmita tanggal 9 Juli 1980, yang bergerak dalam pelayanan kesehatan masyarakat. Rumah sakit ini mulai beroperasi pada tanggal 12 Juli 1992. Saat ini RSKB Halmahera Siaga beroperasi dengan jumlah 30 tempat tidur berada di lokasi yang strategis di pusat kota Bandung.

RSKB Halmahera Siaga dalam perkembangannya sejak awal berdirinya merupakan klinik atau tempat praktek beberapa orang dokter Orthopaedi yang akhirnya berkembang menjadi rumah sakit bedah dengan orthopaedi sebagai layanan unggulannya.

Meskipun dari data diatas orthopaedi menjadi unggulan layanan, namun berdasarkan data pula, terdapat fenomena dimana kunjungan pasien yang datang dari tahun 2012 sampai dengan 2014 yang datang ke Poliklinik Orthopaedi sangat fluktuatif, telah terjadi penurunan yang sangat signifikan pada tahun 2014.

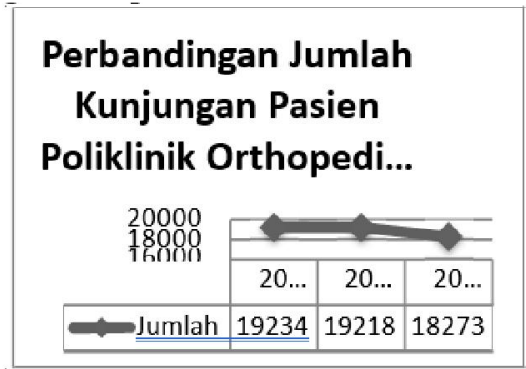

Gambar 1. Kunjungan

PasienPoliklinik Orthopaedi Tahun 2012-2014

Disamping itu pula, dari data sekunder yang diambil dari evaluasi Kinerja Divisi pelayanan ternyata terdapat fenomena lain yaitu rendahnya pasien dari poliklinik yang mau atau bersedia untuk dirawat atas indikasi medis maupun dilakukan tindakan medis. Dari wawancara awal terhadap pasien poliklinik yang diindikasikan tindakan lebih lanjut tetapi menolak terdapat beberapa alasan yang dikemukanan yaitu baik karena alasan keberatan biaya atau alasan lain (pelayanan lambat dan fasilitas pelayanan), pasien memilih berpindah ke rumah sakit lain atau melakukan pengobatan secara tradisional dengan berobat ke "bengkel tulang". Oleh karena itu pasien yang bersedia dirawat atau bersedia dilakukan tindakan medis dari pelayanan Poliklinik Orhtopaedi RSKB Halmahera Siaga sangat rendah.

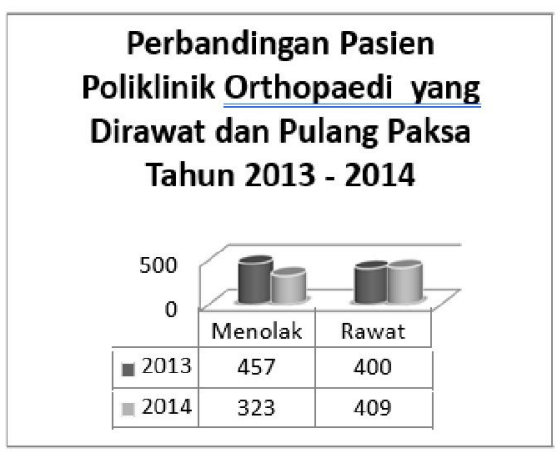

Gambar 2. Perbandingan Pasien Poliklinik Orthopaedi yang Dirawat dan Pulang Paksa Tahun 2013 - 2014

Hal ini terlihat berdasarkan grafik di atas terlihat bahwa perbandingan pasien rawat jalan di Poliklinik Orthopaedi pada tahun 2014 yang masuk dirawat sebanyak 409 org $(56 \%)$ dan yang menolak rawat sebanyak 323 org (44\%) dari potensi pasien yang perlu dilakukan tindakan medis/ dirawat lebih lanjut sebanyak 
732 pasien. Bila dibandingkan dengan tahun sebelumnya potensi pasien rawat alan di Poliklinik Orthopeadi pada tahun 2014 lebih sedikit dibandingkan pada tahun 2013 yaitu sebanyak 857 pasien, hal ini disebabkan karena adanya penurunan jumlah kunjungan pasien ke Poliklinik Orthopaedi.

Dari keterangan dan data-data diatas telah terjadi beberapa fenomena yaitu kunjungan pasien yang berobat ke poliklinik Orthopaedi pada tahun 2012,2013, dan 2014 sangat fluktuatif malah cenderung menurun pada tahun 2014, kemudian adanya penolakan tindakan yang banyak terjadi di poliklinik Orthopaedi dikarenakan alasan biaya dan alasan lain, oleh karena itu meskipun citra merek telah terbangun dalam kunjungan pasien yang sebagian besar ke layanan orthopaedi RSKB Halmahera Siaga, penulis ingin mengetahui sejauh mana Loyalitas Pasien yang terbangun setelah mendapat pelayanan kesehatan di Poliklinik Orthopaedi. Oleh karena itu penulis tertarik untuk melakukan penelitian mengenai Pengaruh Citra Merek Terhadap Loyalitas Pasien Di Poliklinik Orthopaedi Rumah Sakit Khusus Bedah Halmahera SiagaBandung.

\section{Temuan Dan Pembahasan}

\section{Analisis Jalur}

Method of Successive Interval (MSI)

Tahap pertama adalah menkonversi data dari skala ordinal menjadi skala interval dengan menggunakan metode MSI (Methode of Successive Interval) dengan hasil disajikan pada lampiran. Data yang telah berbentuk interval kemudian diklompokkan per variabel dengan cara menjumlahkan skornya, sehingga diperoleh skor X1, X2, X3, $\mathrm{X} 4$ dan $\mathrm{Y}$ yang kemudian akan dianalisis lebih

\section{Uji Normalitas Data}

Uji normalitas digunakan untuk mengetahui apakah data berdistribusi normal atau tidak berdistribusi normal. Pengujian normalitas pada penelitian ini menggunakan uji KolmogorovSmirnov. Berikut disajikan hasil output program SPSS 13.0 uji normalitas data dengan menggunakan uji KolmogorovSmirnov.

Tabel 2. Hasil Uji Normalitas

\begin{tabular}{|c|c|c|}
\hline \multicolumn{3}{|c|}{ One-Sample Kolmogorov-Smirnov Test } \\
\hline & & $\begin{array}{c}\text { Unstandardized } \\
\text { Residual }\end{array}$ \\
\hline $\bar{N}$ & & 224 \\
\hline \multirow{2}{*}{ Normal Parameters ${ }^{a, b}$} & Mean & .0000000 \\
\hline & Std. Deviation & 2.71276996 \\
\hline Most Extreme & Absolute & .079 \\
\hline \multirow[t]{2}{*}{ Differences } & Positive & .041 \\
\hline & Negative & -.079 \\
\hline Kolmogorov-Smirnov Z & & 1.182 \\
\hline Asymp. Sig. (2-tailed) & & .122 \\
\hline
\end{tabular}

Berdasarkan tabel diatas diperoleh nilai Kolmogorov-Smirnov sebesar 1,182 dengan nilai sig $=0,122$. Dikarenakan nilai sig. $>0,05$, maka dapat disimpulkan bahwa residual data berdistribusi normal.

\section{Perhitungan Analisis Jalur}

Analisis ini meneliti tentang pengaruh bebas jasa yang terdiri dari 4 (empat) variabel yakni jenis Asosiasi Mereka yang Digunakan (X1),

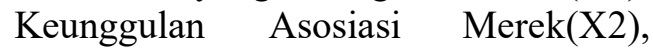
Kekuatan dari Asosiasi Merek(X3) dan Keunikan dari Asosiasi $\operatorname{Merek(X4)}$ terhadap Loyalitas Pasien(Y).

Tahap pertama adalah mencari koefisien jalur untuk mencari pengaruh dari variabel bebas (X) terhadap kualitas pelayanan (Y). Dari hasil pengolahan data diperoleh matriks korelasi antar variabel bebas (X) seperti di bawah ini: 
112 Bernadetta Echalaksmidewi Yudhasari Sukowati

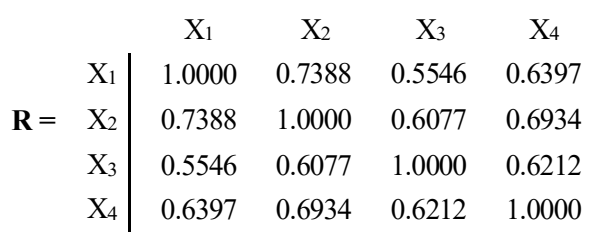

Nilai korelasi antar variabel di atas kemudian dicari invers-nya, dan diperoleh hasil sebagai berikut:

$$
\mathbf{R}^{-1} \equiv \mathrm{X}_{1} \mathrm{X}_{2} \mathrm{X}_{3}\left[\begin{array}{cccc}
\mathrm{X}_{1} & \mathrm{X}_{2} & \mathrm{X}_{3} & \mathrm{X}_{4} \\
2.3974 & -1.2798 & -0.2449 & -0.4942 \\
-1.2798 & 2.8189 & -0.4846 & -0.8350 \\
-0.2449 & -0.4846 & 1.8308 & -0.6447 \\
-0.4942 & -0.8350 & -0.6447 & 2.2956
\end{array}\right]
$$

Perhitungan matriks korelasi antar variabel bebas $\mathrm{X}$ dengan $\mathrm{Y}$ :

$$
\mathbf{R}_{y x}=\begin{gathered}
\mathrm{X}_{1} \\
\mathrm{X}_{2}
\end{gathered}\left[\begin{array}{c}
\mathrm{Y} \\
\mathrm{X}_{3} \\
\mathrm{X}_{4}
\end{array}\left[\begin{array}{c}
0.5460 \\
0.4859 \\
0.5612
\end{array}\right]\right.
$$

Untuk memperoleh koefisien jalur, maka matriks invers korelasi dikalikan dengan matriks korelasi antar variabel bebas $\mathrm{X}$ dengan variabel terikat Y, sebagai berikut:

$\begin{aligned} & \text { PYX }_{1} \\ & \text { PYX }_{2} \\ & \text { PYX }_{3} \\ & \text { PYX }_{4}\end{aligned}=\left[\begin{array}{cccc}2.3974 & -1.2798 & -0.2449 & -0.4942 \\ -1.2798 & 2.8189 & -0.4846 & -0.8350 \\ -0.2449 & -0.4846 & 1.8308 & -0.6447 \\ -0.4942 & -0.8350 & -0.6447 & 2.2956\end{array}\right] \times\left[\begin{array}{l}0.6176 \\ 0.5460 \\ 0.4859 \\ 0.5612\end{array}\right]$

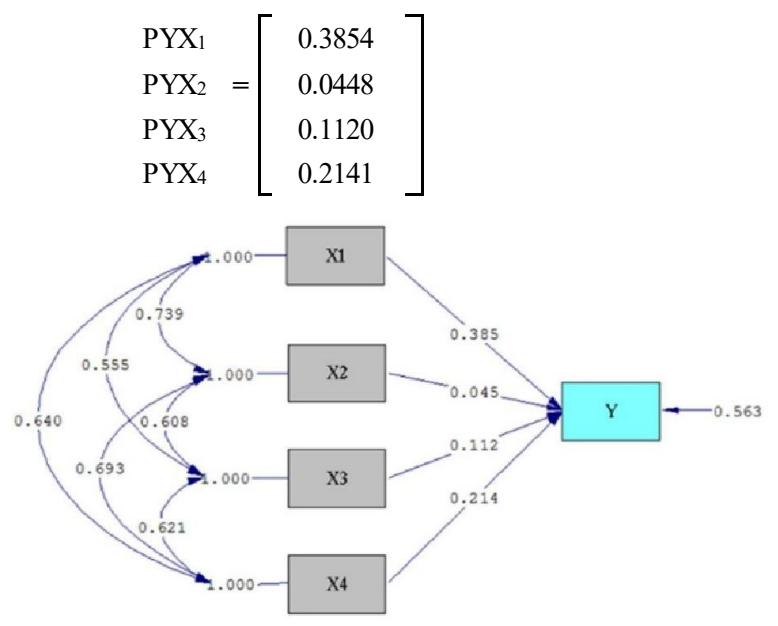

Gambar 3. Diagram Jalur Nilai Koefisien Korelasi

Setelah koefisien jalur diperoleh, maka besar pengaruh Jenis Asosiasi Merek yang Digunakan ( $\left.\mathrm{X}_{1}\right)$, Keunggulan Asosiasi $\operatorname{Merek}\left(\mathrm{X}_{2}\right)$, Kekuatan dari Asosiasi Merek( $\left.\mathrm{X}_{3}\right)$ dan Keunikan dari Asosiasi $\operatorname{Merek}\left(\mathrm{X}_{4}\right)$ secara bersama-sama terhadap Loyalitas Pasien(Y) dapat ditentukan dari hasil perkalian koefisien jalur terhadap matriks korelasi antara variabel sebab $\mathrm{X}$ dengan variabel akibat $Y$.

$$
\begin{gathered}
R_{Y(X \times 1 \times 2 \times 1)}^{2}=\left[\begin{array}{llll}
0.3854 & 0.0448 & 0.1120 & 0.2141
\end{array}\right] \times\left[\begin{array}{l}
0.6176 \\
0.5460 \\
0.4859 \\
0.5612
\end{array}\right] \\
=0,437=43,702 \%
\end{gathered}
$$

Sedangkan besar koefisien jalur untuk faktor lain yang tidak masuk dalam spesifikasi adalah

Py $\varepsilon=\sqrt{0,437} 0,750$

Atau, dalam prosentase besarnya pengaruh dari variabel lain yang tidak diamati adalah sebesar adalah sebesar 56,298\%.

Dari hasil analisa diatas terlihat bahwa hanya sebesar 43, $702 \%$ yang teranalisa sedangkan sebesar 56,298\% yang tidak dianasisa dikarenakan faktor lain yang tidak diteliti.

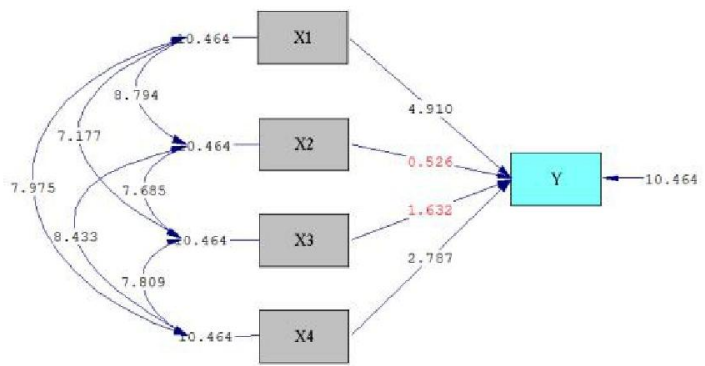

Berdasarkan penelitian yang telah dilakukan mengenai pengaruh citra merek terhadap loyalitas pasien di poliklinik Orthopaedi RSKB Halmahera Siaga Bandung didapatkan hasil bahwa: 
Jenis Asosiasi Merek yang Digunakan $\left(X_{1}\right)$ berpengaruh signifikan terhadap Loyalitas Pasien $\left(t_{\text {hitung }}(4,910)>t_{\text {tabel }}(1,971)\right)$

Berdasarkan hasil penelitian yang dilakukan kepada 224 responden yang berobat ke poliklinik orthopaedi RSKB Halmahera Siaga, ternyata jenis asosiasi merek berpengaruh signifikan sebesar $23,802 \%$ terhadap loyalitas pasien dimana variabel Jenis Asosiasi Merek yang Digunakan $\left(\mathrm{X}_{1}\right)$ mempengaruhi Loyalitas Pasien secara langsung sebesar $14,856 \%$, sedangkan pengaruh tidak langsung variabel terhadap Loyalitas Pasien sebesar $8,947 \%$.

Meskipun berpengaruh signifikan, namun dilihat dengan hanya $23,802 \%$, hal ini harus menjadi evaluasi bagi manjemen rumah sakit untuk bisa lebih mengembangakan layanannya. Ungkapan Keller bahwa Jenis asosiasi merek yang digunakan adalah atribut-atribut merek (brand attributes), manfaat merek (brand benefit), dan konsepsi (conception). Atribut merek (brand attributs) adalah fitur deskriptif yang menjadi ciri suatu produk atau jasa. . Cooper (1994:392) berdasarkan beberapa penelitian citra rumah sakit dipengaruhi oleh faktorfaktor sebagai berikut: kualitas dokter, fasilitas perawatan dan teknologi, fasilitas diagnose, kualitas perawatan keseluruhan, perhatian interpersonal, kesadaran staf terhadap kebutuhan personal pasien, kontrol pasien dari pengalaman rumah sakit,lokasi dan biaya,kemudahan dari lokasi.

Bagi pelayanan rumah sakit hal ini sangat penting terutama kaitannya dengan pelayanan kesehatan. Manfaat bagi pasien harus bisa dirasakan sehingga timbul suatu loyalitas pasien terhadap pelayanan suatu rumah sakit. Di RS Khusus Bedah Halmahera Siaga terutama di poliklinik orthopaedi beberapa hal sudah dapat dijalankan dan dapat dirasakan oleh pasien yang berobat, namun juga banyak responden merasakan bahwa terutama fasilitas fisik masih kurang dimaksimalkan. Oleh karena itu berkaitan dengan hasil penelitian yang telah dilakukan meskipun terjadi hasil yang signifikan namun banyak hal yang harus dijadikan dasar bagi manejemen untuk mengembangkan layanannya. Dari hasil penelitian, untuk pertanyaanpertanyaan yang dijawab oleh responden baik terutama kaitannya dengan hasil wawancara awal terhadap pasien bahwa poliklinik orthopaedi dirasakan mahal ternyata setelah dilakukan penelitian dianggap wajar dan terjangkau. Hal ini harus menjadi evaluasi apakah ada faktor-faktor lain yang menyebabkan adanya persepsi maupun asoasisi terhadap hal itu. Secara umum kualitas pelayanan di poliklinik Orthopaedi cukup baik, terutama tingkat profesionalisme dokter dan perawat, kecepatan pelayanan. Pasien juga merasakan jaminan kesembuhan ketika berobat ke poliklinik orthopaedi RSKB Halmahera Siaga Bandung.Rumah sakit merupakan suatu sistem yang saling berkaitan yang harus memberikan manfaat, oleh kerana itu pelayanan harus diberikan oleh rumah sakit adalah:

1. Pelayanan medis, merupakan bidang jasa pokok rumah sakit, pelayanan ini diberikan oleh tenaga medis yang profesional dalam bidangnya baik dokter umum, maupun spesialis.

2. Pelayanan keperawatan, merupakan pelayanan yang bukan tindakan medis terhadap pasien, tetapi merupakan tindakan keperawatan yang dilakukan oleh perawat sesuai aturan keperawatan.

3. Pelayanan penunjang medis, ialah pelayanan penunjang yang 
diberikan terhadap pasien, seperti: pelayanan gizi, laboratorium, farmasi, fisioterapi, dan lainnya.

4. Pelayanan administrasi dan keuangan, pelayanan administrasi yang dilakukan berupa bidang ketata usahaan seperti pendaftaran, rekam medis, dan kerumahtanggaan, pemasaran sedangkan bidang keuangan meliputi proses pembayaran biaya rawat jalan untuk poliklinik, biaya pasien rawat inap untuk pasien selama dirawat di rumah sakit tersebut.

Pelayanan poliklinik juga tidak akan lepas dari pelayanan rumah sakit secara umum, bagian pendukung layanan harus ditingkatkan agar memperkuat pelayanan, hal pendukung inilah yang kadangkala menjadi faktor utama untuk menumbuhkan loyalitas bagi pasien untuk datang berobat kembali. Oleh karena itu jenis asosiasi merek dapat menanamkan image yang positif terhadap loyalitas pasien di Poliklinik Orthopaedi RSKB Halmahera Siaga.

\section{Keunikan dari Asosiasi Merek(X4) berpengaruh signifikan terhadap Loyalitas Pasien (t hitung $(2,787)>$ $t$ tabel (1,971))}

Berdasarkan hasil penelitian yang dilakukan kepada 224 responden yang berobat ke poliklinik orthopaedi RSKB Halmahera Siaga, ternyata keunikan asosiasi merek berpengaruh signifikan sebesar $12,014 \%$. terhadap loyalitas pasien Dimana variabel Keunikan dari Asosiasi Merek $\left(\mathrm{X}_{4}\right)$ mempengaruhi Loyalitas Pasien secara langsung sebesar $4,582 \%$, sedangkan pengaruh tidak langsung variabel terhadap Kualitas Pelayanan sebesar $7,432 \%$.
Berdasarkan hasil penelitian meskipun keunikan berpengaruh signifikan terhadap loyalitas pasien di poliklinik orthopaedi RS Khusus Bedah Halmahera Siaga, namun dilihat dari hasil signifikannya yang hanya $12,014 \%$ terlihat sangat rendah, hal ini dimungkinkan adanya faktor lain yang tidak teliti dalam penelitian ini. Berdasarkan hasil penelitian terdapat temuan bahwa kebanyakan responden menjawab kadang baik kredibilitas yang sejajar dengan poliklinik di rumah sakit lain, komunikasi pemasaran yang sesuai dengan pelaksanaan di poliklinik orthopaedi dan adanya informasi pemasaran yang selalu dilakukan untuk jangka waktu yang lama. Hal ini perlu dilakukan evaluasi bagi manajeman rumah sakit untuk meningkatkan pelayanan terutama di bidang pemasaran rumah sakit. Menurut Boy S. Sabarguna (2004:1), perbedaan antara pemasaran rumah sakit dengan pemasaran jasa pada umumnya yaitu:

1. Produknya berupa pelayanan yang hanya dapat menjanjikan usaha, bukan menjadi hasil.

2. Pasien hanya akan menggunakan pelayanan bila diperlukan, walaupun sekarang ini ia tertarik.Tidak selamanya tarif berperan penting dalam pemilihan, terutama pada kasus dalam keadaan darurat.

3. Pelayanan hanya dapat dirasakan pada saat digunakan, dan tidak dapat dicoba secara leluasa.

4. Fakta akan lebih jelas pengaruhnya dari pada hanya pembicaraan belaka.

Oleh karena itu pemasaran rumah sakit perlu dilakukan secara maksimal . memberikan kesan unik, menunjukkan perbedaan yang berarti diantara brand lain sebagai nilai saing, sehingga membuat pasien tidak mempunayi alasan lain untuk memilih 
poliklinik lain selain poliklinik orthopaedi RSKB Halmahera Siaga mempunyai nilai signifikan terhadap munculnya loyalitas pasien . Oleh karena itu Keunikan dari Asosiasi Merek dapat menanamkan image positif terhadap loyalitas pasien.

\section{Kekuatan dari Asosiasi Merek (X3) tidak berpengaruh signifikan terhadap Loyalitas Pasien (t hitung $(1,632)<\mathrm{t}$ tabel $(1,971))$}

Berdasarkan hasil penelitian yang dilakukan kepada 224 responden yang berobat ke poliklinik orthopaedi RSKB Halmahera Siaga, ternyata kekuatan asosiasi merek berpengaruh tidak signifikan sebesar 5,441\%. terhadap loyalitas pasien dimana variabel Kekuatan dari Asosiasi Merek $\left(\mathrm{X}_{3}\right)$ mempengaruhi Loyalitas Pasien secara langsung sebesar 1,254\%, sedangkan pengaruh tidak langsung variabel terhadap Loyalitas Pasien sebesar $4,187 \%$.

$$
\text { Berdasarkan Keller (2003) }
$$

Asosiasi merek yang kuat dapat dihasilkan oleh kedalaman berfikir seseorang tentang informasi produk dan dihubungkan dengan pengetahuan merek yang telah ada. Dua faktor yang yang dapat memperkuat asosiasi dengan informasi adalah hubungan personal dan konsistensi dari informasi yang disampaikan.

$$
\begin{aligned}
& \text { Berdasarkan hasil penelitian } \\
& \text { yang dilakukan ternyata }
\end{aligned}
$$

kekuatan asosiasi merek tidak berpengaruh secara signifikan terhadap loyalitas pasien di poliklinik orthopaedi RS Khusus Bedah Halmahera Siaga, hal tersebut dapat terlihat bahwa kekuatan dari poliklinik orthopaedi belum bisa dijadikan dasar munculnya loyalitas pasien. Perlu dilakukan upaya untuk bisa mngembangkan kekuatan asosiasi merek poliklinik orthopaedi dengan cara melihat faktor-faktor lain pendukung kekuatan assosiasi merek. Pada saat ini Rumah Sakit Halmahera Siaga sedang melakukan perbaikan - perbaikan terutama perbaikan fasilitas fisik maupun system palayanan dengan penyusunan ulang standar operasional prosedur baik di bagian pelayanan, peunjang pelayanan maupun di bagian keuangan. Diharapkan hal tersebut bisa dijadikan kekuatan baru untuk membuat citra merek menjadi lebih kuat sehingga diharapkan bisa meningkatkan loyalitas pasien yang datang. Oleh karena itu Kekuatan dari Asosiasi Merek belum dpat menanakan image yang positif terhadap Loyalitas Pasien

\section{Keunggulan Asosiasi Merek (X $\left.\mathbf{X}_{2}\right)$ tidak berpengaruh signifikan terhadap Loyalitas Pasien (t hitung $(0,526)<t$ tabel $(1,971))$}

Berdasarkan hasil penelitian yang dilakukan kepada 224 responden yang berobat ke poliklinik orthopaedi RSKB Halmahera Siaga, ternyata kekuatan asosiasi merek berpengaruh tidak signifikan sebesar 2,445\% terhadap loyalitas pasien dimana variabel Keunggulan Asosiasi Merek $\left(\mathrm{X}_{2}\right)$ mempengaruhi Loyalitas Pasien secara langsung sebesar 0,201\%, sedangkan pengaruh tidak langsung variabel terhadap Loyalitas Pasiensebesar 2,245\%.

Keunggulan asosiasi merek dapat membuat konsumen percaya bahwa atribut dan manfaat yang diberikan oleh suatu merek dapat memuaskan kebutuhan dan keinginan konsumen sehingga menciptakan sikap yang positif terhadap merek tersebut (Keller, 2008:58).

Dari hasil penelitian di poliklinik Orthopaedi RS Khusus Bedah Halmahera Siaga ternyata keunggulan asosiasi merek tidak berpengaruh secara signifikan terhadap loyalitas pasien yang datang. Hal ini perlu dijadikan 
evaluasi bahwa rumah sakit belum bisa membuat keunggulan meenjadi dasar yang membuta pasien menjadi loyal.

Dari pertanyaan yang dijawab oleh 224 responden ternyata sebagian besar menjawab biasa saja yaitu kebanggan setelah berobat ke poliklinik orthopaedi, keamanan dan kenyamanan berobat ke poliklinik orthopaedi, ketertarikan terhadap iklan dan komitmen untuk selalu memperbaharui kualitas layanan untuk memberikan pelayanan yang prima. Berdasarkan hal tersebut ternyata banyak sekali hal yang perlu dilakukan bagi manajemen untuk membuat keunggulan asoasiasi merek berpengaruh terhadap loyalitas pasien. Pembangunan fasilitas fisik yang sudah dimulai di rumah sakit dengan konsep yang jelas, meningkatkan pemasaran dengan memperbaiki system pemasaran dan memperbaiki sistem layanan bagi pasien sehingga kualitas layanan dapat selalu diperbaiki. Oleh karena itu keunggulan asosiasi merek belum dapat menanamkan image yang positif terhadap loyalitas pasien.

\section{Simpulan dan Saran}

Dari hasil penelitian mengenai

Pengaruh Citra Merek terhadap Loyalitas Pasien di Poliklinik Orthopaedi Rumah Sakit Khusus Bedah Halmahera Siaga-Bandung, maka penulis dapat menarik kesimpulan sebagai berikut:

1. Berdasarkan perhitungan statistik deskriptif data penelitian Pengaruh Citra Merek terhadap Loyalitas Pasien di Poliklinik Orthopaedi RS Khusus Bedah Halmahera Siaga Bandung, untuk variabel Jenis Asosiasi Merek yang Digunakan termasuk dalam kategori baik, data penelitian variabel Keunggulan Asosiasi Merek termasuk dalam kategori cukup baik, data penelitian variabel Kekuatan dari Asosiasi Merek termasuk dalam kategori baik, dan data penelitian variabel Keunikan dari Asosiasi Merek termasuk dalam kategori baik.

2. Untuk Loyalitas pasien yang berobat di Poliklinik Orthopaedi RS Khusus Bedah Halmahera Siaga, Bandung, berdasarkan perhitungan statistik deskriptif data penelitian variabel Loyalitas Pasien termasuk dalam kategori cukup baik.

3. Hasil penelitian kepada pasien yang berobat di Poliklinik Orthopaedi RS Khusus Bedah Halmahera Siaga-Bandung, untuk variabel Jenis Asosiasi Merek yang Digunakan $\left(\mathrm{X}_{1}\right)$ berpengaruh signifikan terhadap Loyalitas Pasien sebagaimana telah di sajikan pada uji-t dengan total pengaruh sebesar 23,802\%, terdiri atas pengaruh langsung sebesar $14,856 \%$ dan pengaruh tidak langsung sebesar $8,947 \%$

4. Hasil penelitian kepada pasien yang berobat di Poliklinik Ortopaedi RS Khusus Bedah Halmahera Siaga-Bandung, untuk variabel Keunggulan Asosiasi Merek $\left(\mathrm{X}_{2}\right)$ berpengaruh terhadap Loyalitas Pasien (Y) namun tidak signifikan, sebagaimana telah di sajikan pada uji-t dengan total pengaruh sebesar $2,445 \%$, terdiri atas pengaruh langsung sebesar $0,201 \%$ dan pengaruh tidak langsung sebesar 2,245\%.

5. Hasil penelitian kepada pasien yang berobat di Poliklinik Ortopaedi RS Khusus Bedah Halmahera Siaga-Bandung, untuk variabel Kekuatan dari Asosiasi Merek $\left(\mathrm{X}_{3}\right)$ 
berpengaruh terhadap Loyalitas

Pasien (Y) namun tidak signifikan, sebagaimana telah di sajikan pada uji-t dengan total pengaruh sebesar $5,441 \%$, terdiri atas pengaruh langsung sebesar $1,254 \%$ dan pengaruh tidak langsung sebesar 4,187\%.

6. Hasil penelitian kepada pasien yang berobat di Poliklinik Ortopaedi RS Khusus Bedah Halmahera Siaga-Bandung, untuk variabel Keunikan dari Asosiasi Merek $\left(\mathrm{X}_{4}\right)$ berpengaruh signifikan terhadap Loyalitas Pasien sebagaimana telah di sajikan pada uji-t dengan total pengaruh sebesar 12,014\%, terdiri atas pengaruh langsung sebesar $4,582 \%$ dan pengaruh tidak langsung sebesar 7,432\%.

7. Secara simultan variabel Citra Merek (Brand Image) melalui indikator jenis asosiasi yang digunakan (types of brand association), keungulan asosiasi merek (Favorability of brand association), kekuatan asosiasi merek (Strength of brand association) dan kenukan

8. asosiasi merek (Uniqueness of brand association) berpengaruh signifikan terhadap Loyalitas Pasien dengan total pengaruh sebesar 43,702\%, sedangkan sisanya sebesar 56,298\% adalah pengaruh dari variabel lain yang tidak diamati.

Berdasarkan hasil penelitian dengan judul Pengaruh Citra Merek terhadap Loyalitas Pasien di Poliklinik Orthopaedi Rumah Sakit Khusus Bedah Halmahera Siaga, ada beberapa saran yang peneliti sampaikan baik bagi Program Studi Magister Manajemen Konsentrasi Manajemen Rumah Sakit Universitas Islam Bandung dan Rumah
Sakit Khusus Bedah Halmahera Siaga Bandung, yaitu:

1. Dikarenakan keterbatasan waktu dan kemampuan peneliti dimana adanya faktor-faktor lain yang berpengaruh pada hasil penelitian tersebut,peneliti mengharapkan dapat dilakukan penelitian ulang dengan judul yang sama dan variabel yang sama terhadap faktor-faktor lain yang mempengaruhi hasil penelitian seperti faktor budaya, adat istiadat atau kebiasaan.

2. Berdasarkan hasil penelitian dimana banyak pasien yang meras tidak puas terhadap keindahan, kenyamanan fasilitas fisik di poliklinik orthopaedi RS Khusus Bedah Halmahera Siaga, penulis sarankan perlu adanya percepatan pembangunan fisik rumah sakit baik dari segi tata ruang, keindahan dan kebersihan di lingkungan Rumah Sakit Halmahera Siaga, koordinasi dibagian kesehatan lingkungan dan bagian umum dalam meningkatkan keindahan, merevisi kembali tentang standar prosedur Operation (SOP) untuk menjaga kebersihan di lingkungan rumah sakit termasuk juga terhadap out soucing cleaning service.

3. Berdasarkan hasil jawaban responden bahwa kurang maksimalnya pemasaran di RS Khusus Bedah Halamhera Siaga, baik dikarenakan kurangnya sumber daya manusia dan belum adanya program pemasaran yang baik, penulis sarankan perlu adanya penambahan tenaga di bagian pemasaran sehingga pemasaran eksternal dan internal melalui Humas bisa dilakukan dengan maksimal, kerjasama dengan institusi lain baik dengan 
perusahaan-perusahaan swasta dan asuransi lain. Program Humas untuk bisa lebih fokus dipelayanan internal rumah sakit dengan memperbaiki iklan, mengevaluasi pelayanan dengan dibuatnya angket dan masukan bagi pasien, kotak saran dan menerima permasalahan pasien setiap saat.

4. Berdasarkan hasil penelitian terlihat bahwa secara kualitas pelayanan baik dokter dan tenaga perawat sudah professional, namun dengan banyaknya rumah sakit lain yang muncul di kota Bandung, penulis sarankan untuk dilakukan pelatihan berkala untuk tenaga dokter dan perawat baik internal maupun eksternal. Dengan kemampuan dokter dan perawat yang profesional ini juga disarankan bahwa RS Halmahera Siaga bisa membuat atau mengadakan pelatihan untuk bagi puskesmaspuskesmas atau rumah sakit lain terutama dalam pelayanan orthopaedi sehingga hal ini bisa menjadi bentuk pemasaran bagi rumah sakit.

5. Dikarenakan sudah adanya website yang dibuat oleh RS Halmahera Siaga yang sampai saat ini belum bisa secara maksimal dijadikan sebagai bentuk pemasaran dari RS Khusus Bedah Halmahera Siagam penulis sarankan untuk merekruit tenaga yang memang ahli dan mampu untuk bisa menjalankan website dengan baik dan maksimal sehingga bisa menjadi salah satu bentuk pemasaran yang baik.

6. Dari hasil data responden yang datang berobat ke Poliklinik Orthopaedi RS Khusus Bedah
Halmahera Siaga kebanyakan wanita dengan usia diantara 4150 tahun, dengan tingkat pendidikan kebanyakan S1 dengan pendapatan diatas ratarata, penulis sarankan untuk dibuat suatu kelompok bagi pasien-pasien penderita penyakit diakibatkan faktor usia (degenerative) misalnya Kelompok Osteoatritis, Kelompok

Osteoporosis.Kelompok ini bisa dikelola oleh bagian Pendidikan dan Pelatihan RSKB Halmahera Siaga dengan dibuat satu program pelatihan dan pendidikan sehinggga pasien penderita penyakit degenerative tersebut bisa dievaluasi setiap saat dan di atasi masalahnya.

7. Dari hasil penelitian bahwa kekuatan dan keunggulan asosiasi merek tidak berpengaruh secara signifikan terjadap loyalitas pasien, perlu dilakuakan evaluasi bagi jajaran manajemen untuk mencari langkah-langkah konkrit untuk bisa memberbaiki baik dari sisi organisasi rumah sakit maupun evaluasi standar prosedur operasional (SPO) di rumah saki, usulan penulis dengan studi banding dengan rumah sakit sejenis sebagai penyegaran untuk rumah sakit membuat peluang yang baru sebagai langkah bisa mengembangkan layanan di rumah saki tselain itu juga segera mempersiapkan akreditasi rumah sakit sebagai salah satu pengukur kualitas rumah sakit apakah sudah sesuai dengan standar yang ditetapkan oleh pemerintah. 


\section{Daftar Pustaka}

Sabarguna, BoyTesis. Pengaruh physical support terhadap contact personnel pada Rumah Sakit Umum di Sumatera Barat.

Keller, K. L. (2003). Strategic Brand Management: Building, Measuring, and Managing Brand Equity Second Edition. New Jersey: Pearson Education, Inc.

Keller, K. L. (2008). Strategic Brand Management: Building, Measuring, and Managing Brand Equity Third Edition. New Jersey: Pearson Education, Inc.

Rangkuti, Freddy . Strategi Promosi yang Kreatif dan AnalisisKasus Integrated Marketing Communication. Jakarta : PT. GramediaPustakaUtama. Jakarta .2009 